\title{
PENGEMBANGAN MULTIMEDIA INTERAKTIF BERBASIS KONTEKSTUAL BUDAYA BALI PADA PEMBELAJARAN DESIGN GRAFIS DI KELAS X MULTIMEDIA SMK NEGERI 1 SAWAN
}

\author{
I Gede Jaka Mahendra \\ Politeknik Ganesha Guru, Denpasar, Bali \\ jakamahendra.ig@gmail.com \\ Kadek Agus Hendra Pujawan \\ Politeknik Ganesha Guru, Denpasar, Bali \\ hendrapoltekG2Stikom@gmail.com
}

\begin{abstract}
Abstrak
Penelitian ini bertujuan untuk mengembangkan multimedia interaktif berbasis kontekstual budaya bali yang berkualitas dan siap diimplementasikan pada pembelajaran desain grafis di Kelas X SMK Negeri 1 Sawan. Model pengembangan yang digunakan adalah model Dick \& Carey yang terdiri dari 8 tahapan. Multimedia yang dihasilkan divalidasi oleh pakar desain grafis yang selanjutnya diujikan secara perorangan dan kelompok kecil untuk memperoleh respons pengguna. Hasil pengujian menunjukkan bahwa pada aspek tampilan, grafis, pengoperasian program dan tata bahasa yang dilakukan oleh ahli media memperoleh hasil kalkulasi sebesar $85 \%$ berada pada kualifikasi baik. Pengujian pada aspek pembelajaran, kurikulum dan desain interface yang dilakukan oleh ahli desain pembelajaran memperoleh hasil kalkulasi sebesar $89 \%$ berada pada kualifikasi baik. User/guru pengajar memberikan respon baik. Uji coba perseorangan yang dilakukan mendapat respon baik. Uji coba kelompok kecil memperoleh hasil kalkulasi sebesar $90 \%$ berada pada kualifikasi sangat baik. Uji coba lapangan yang dilakukan memperoleh hasil kalkulasi sebesar $87 \%$ berada pada kualifikasi baik.
\end{abstract}

Kata Kunci: Multimedia Interaktif, Dick and Carey, Design grafis

\begin{abstract}
This study aims to develop multimedia-based interactive multimedia in Bali that is ready to be implemented in graphic design learning in Class X of SMK Negeri 1 Sawan. The development model used is the Dick \& Carey model which consists of 8 stages. Multimedia is validated by graphic design experts who are then tested individually and in small groups to collect the reponses toward the multimedia being developed. The test results show that the display, graphics, program operation and grammar aspects performed by media experts obtain a calculation result of $85 \%$ in good qualification. Tests on aspects of learning, curriculum and interface design carried out by learning design experts obtain results of calculations of $89 \%$ in good qualifications. The user / teacher gives a good response. The individual trials carried out received a good response. Small group trials obtained results of a calculation of $90 \%$ in very good qualifications. The field trials conducted obtained a calculation result of $87 \%$ in good qualifications.
\end{abstract}

Keywords: Interactive Multimedia, Dick and Carey, Grafic design

\section{Pendahuluan}

Di era globalisasi saat ini, pemahaman dan penerapan teknologi informasi sangat diperlukan. Peran Teknologi Informasi telah merambah ke segala bidang, salah satunya termasuk bidang pendidikan. Peran Teknologi Informasi dalam bidang pendidikan adalah membantu memberikan informasi/pesan pendidikan kepada komponen-komponen pendidikan. Penggunaan alat bantu berbasis Teknologi Informasi memiliki daya tarik baik dari tenaga pengajar maupun peserta didik dengan harapan dapat memberikan sumbangan yang efektif dan efisien bagi pencapaian tujuan pendidikan lebih optimal.

Salah satu sekolah yang telah berusaha mengembangkan multimedia dalam proses pembelajaran adalah SMK Negeri 1 Sawan, Kecamatan Buleleng, akan tetapi pada kenyataanya di sekolah tidak terlaksana sepenuhnya, karena kurangnya SDM di bidang pembuatan dan pengelola multimedia interaktif, selain itu media yang tersedia bersifat linear tanpa adanya pengontrol sehingga tampilan yang disajikan sekuensial yang tidak sesuai dengan karakter peserta didik di kelas X Multimedia SMK Negeri 1 Sawan.

Berdasarkan wawancara terhadap guru mata pelajaran dasar design grafis, mata pelajaran dasar design grafis memerlukan waktu lama untuk memahami dan mempraktikanya, sedangkan alokasi waktu disekolah sangat kurang. Jadi sangat diperlukan alat bantu dalam proses pembelajaran. Selain itu, jumlah komputer sebagai alat 
praktikum di sekolah membuat beberapa peserta didik tidak mampu mengikuti pelajaran dengan optimal, walaupun sudah belajar kelompok. Di sisi lain, berdasarkan hasil wawancara dan analisis karakteristik siswa di SMK Negeri 1 Sawan kebanyakan berasal dari pedesaan sehingga harapan dalam pengembangan multimedia interaktif menggunakan pendekatan kontekstual yang berbudaya Bali, selain itu peserta didik lebih suka belajar dengan melihat tayangan animasi, sehingga multimedia interaktif dalam penayangan teorinya menggunakan animasi dengan harapan bisa meningkatkan respon siswa dalam proses pembelajaran design grafis.

Melihat masalah dan kondisi tersebut, perlu di kembangkan sebuah pembelajaran berbasis audio visual/multimedia, karena memberikan potensi besar dalam merubah cara seseorang untuk belajar, baik memperoleh informasi sampai menyesuaikan suatu informasi. Multimedia juga menyediakan peluang bagi pendidik untuk mengembangkan teknik, Metode dan strategi pembelajaran. dengan multimedia diharapkan peserta didik akan lebih mudah untuk menentukan dengan apa dan bagaimana memahami informasi secara cepat dan efisien.

Penelitian yang dilakukan Mochamad Miswar Hadibin, Bambang Eka Purnama dan Gesang Kritianto (2012) menyebutkan bahwa pembelajaran dengan menggunakan media pembelajaran berbasis multimedia interaktif meningkatkan minat dan respon siswa dalam menerima materi pelajaran. Hal ini ada persamaan dengan hasil pengembangan yang penulis lakukan.

Hal ini sejalan dengan hasil penelitian Ling Wang (2008) dalam penelitiannya mengembangkan software program pembelajaran berbasis multimedia. Hasilnya menunjukan bahwa program yang dikembangkan efektif dalam hal hasil pembelajaran siswa dan memberikan rekomendasi kepada para pendidik untuk mempertimbangkan mengadopsi program tersebut dalam pembelajaran mereka. Lee and Tseng (2008) dalam penelitiannya menyebutkan bahwa, penggunaan instrumen isi digital dalam pembelajaran menghasilkan perbedaan signifikan dalam prestasi siswa, jika dibandingkan dengan pembelajaran tradisional.

\section{Metode}

Jenis penelitian yang dipilih adalah Penelitian dan Pengembangan atau Research and Development $(R \& D)$. Research and Development (R\&D) adalah metode penelitian yang digunakan untuk menghasilkan produk tertentu, dan menguji keefektifan produk tersebut (Sugiyono, 2013:407). Senada dengan pendapat (Ghufron, 2007) Penelitian pengembangan merupakan suatu model penelitian yang bertujuan untuk mengembangkan dan memvalidasi produk pendidikan dan pembelajaran untuk meningkatkan dan mengembangkan mutu pendidikan dan pembelajaran secara efektif dan adaptable. Lebih lanjut pengembangan diartikan sebagai suatu proses penerjemah spesifikasi desain ke dalam bentuk fisik Seels \& Richey (dalam Sudarma \& Tegeh, 2007). Dalam hal ini sudah jelas bahwa tujuan utama dari penelitian pengembangan tersebut adalah bagaimana mendesain dan memproduksi suatu spesifikasi media yang akan dikembangkan.

Terdapat 5 komponen strategi pembelajaran, yaitu: (1) kegiatan pembelajaran pendahuluan, (2) penyampaian materi, (3) partisipasi peserta didik, (4) tes, (5) kegiatan lanjutan. Dalam rangka meningkatkan pemahaman siswa terhadap materi pelajaran dan penguasaan konsep, agar hasil belajar memuaskan diperlukan suatu strategi pembelajaran berbasis TIK yang mampu mengaktifkan siswa dalam proses belajar mengajar menurut Dick \& Carey (dalam Uno 2007). Dalam hal ini dengan menggunakan multimedia interaktif berbasis kontekstual budaya Bali.

Pendekatan yang digunakan dalam penelitian pengembangan multimedia interaktif menggunakan pendekatan kontekstual, Trianto (2008:20) mengatakan bahwa: "pembelajaran kontekstual adalah konsep belajar yang membantu guru mengaitkan antara materi yang diajarkan dengan situasi dunia nyata siswa dan mendorong siswa membuat hubungan antara pengetahuan yang dimilikinya dengan penerapannya dalam kehidupan mereka sehari-hari, namun disesuaikan dengan karakteristik peserta didik di kelas X Multimedia SMK Negeri 1 Sawan yaitu lebih gemar belajar dengan melihat tayangan animasi yang bernuansa budaya Bali, dalam hal ini multimedia interaktif yang dikembangkan di kemas dengan tombol pengontrol yang menyediakan penjelasan teori dengan tampilan animasi dan saat pratikum menggunakan video pemandu dalam pembuatan design. Berikut adalah tahapan menurut Dick and Carey

Tahap 1: Pada tahap awal dalam pengembangan multimedia interaktif berbasis kontekstual budaya Bali ini penulis mempertimbangkan keberhasilan pembuatan multimedia interaktif dan karakter isi yang disajikan, dilihat dari jenis media yang menampilkan tombol interaktif, sound, animasi dan learning guide berupa video panduan belajar, peserta didik akan tertarik mempelajari materi design grafis yang disampaikan pada multimedia interaktif ini. 
Tahap 2: Mata Pelajaran yang dikembangkan dalam multimedia interaktif berbasis kontekstual budaya Bali adalah mata pelajaran dasar design grafis. Design Grafis merupakan mata pelajaran yang diberikan di kelas $\mathrm{X}$ Program keahlian multimedia yang menyajikan materi dasar-dasar design hingga mempraktikan teknik-teknik design menggunakan software Corel draw.

Tahap 3: Langkah yang dilakukan dalam tahapan ini yaitu melakukan proses pengumpulan data terkait kompetensi dasar pada mata pelajaran design grafis, dalam hal ini peneliti mengumpulkan data yang diberikan oleh guru mata pelajaran dasar design grafis.

Tahap 4: Dalam pembelajaran Corel Draw penulis menggunakan sumber berupa buku dan bahan ajar lain yang digunakan di sekolah, selain itu panduan isi content mengadaptasi silabus Kurikulum 2013 SMK Negeri 1 Sawan. sehingga materi yang disajikan di multimedia interaktif sesuai dengan kurikulum design grafis di SMK Negeri 1 Sawan.

Tahap 5 : Karakteristik peserta didik di SMK Negeri 1 Sawan yaitu lebih suka belajar menggunakan bahan ajar berbasis multimedia, yang menuntun kemandirian dalam menyelesaikan suatu masalah dalam pembelajaran design grafis, karena sedikitnya alokasi waktu di sekolah, maka peserta didik bisa belajar di rumah melalui panduan video yang disajikan pada multimedia interaktif.

Tahap 6: Setelah menganalisis kebutuhan dalam pembuatan multimedia interaktif maka selanjutnya menetapkan strategi penyampaian multimedia interaktif berbasis kontekstual budaya Bali, Sebelum memberikan soft copy multimedia interaktif berbasis kontekstual budaya Bali ke peserta didik, terlebih dahulu menjelaskan tata cara penggunaan multimedia interaktif berbasis kontekstual budaya Bali. Dalam strategi penyampaian multimedia interaktif berbasis kontekstual budaya Bali, ilustrasi animasi kartun sebagai penjelasan tentang dasardasar design grafis yang nantinya akan memberikan semangat belajar ke peserta didik, dalam multimedia interaktif berbasis kontekstual budaya Bali terdapat menu latihan soal yang nantinya akan mampu mengevaluasi kemampuan siswa terkait teori design grafis.

Tahap 7: Tahap asembly merupakan tahapan dalam pembuatan multimedia interaktif berbasis kontekstual budaya Bali, tahap asembly meliputi pembuatan rancang bangun multimedia interaktif berbasis kontekstual budaya Bali, dalam tahapan ini dilakukan pembuatan design dengan aplikasi Macromedia Flash 8 yang merupakan aplikasi pembuat multimedia interaktif. Unsur-unsur multimedia seperti gambar, animasi, teks dan sound akan disatukan menjadi sebuah produk multimedia interaktif.

Tahap 8: Uji coba meliputi tanggapan ahli isi, ahli media, ahli disain, dan uji coba lapangan. Masingmasing ahli akan diberikan kuesioner dengan kriteria sesuai dengan keahlian dari para ahli tersebut. Tahap review para ahli terdiri dari ahli isi bidang studi, ahli disain pembelajaran dan ahli media pembelajaran. Ahli isi bidang studi atau mata pelajaran dalam penelitian pengembangan ini adalah guru mata pelajaran design grafis di SMK Negeri 1 Sawan minimal yang berspesifikasi Sarjana. Ahli media dan ahli design media yakni dosen perguruan tinggi lain yang mengampu mata pelajaran design grafis, menguasai dan profesional di bidangnya. Tahap uji coba lapangan dilakukan dengan uji perseorangan yang berjumlah 3 orang siswa, uji kelompok kecil yang berjumlah 8 orang dari siswa yang sudah pernah mendapat materi dasar design grafis yaitu kelas XI danu ntuk uji coba lapangan sudah disediakan angket yang sesuai dengan karakteristik untuk siswa SMK yaitu lebih mengarah pada tampilan visual, audio \& animasi maupun kejelasan teks/tulisan dan kejelasan materi yang disampaikan dalam multimedia interaktif berbasis kontekstual budaya Bali, peserta uji lapangan berjumlah 32 orang siswa kelas $\mathrm{X}$ Multimedia. Data selanjutnya dianalisis menggunakan analisis deskriptif kuantitatif yang selanjutnya dikonversi ke tingkat pencapaian skala lima seperti pada Tabel 1 berikut.

Tabel 1. Konversi Skala 5

\begin{tabular}{ccc}
\hline Tingkat Pencapaian $(\boldsymbol{\%})$ & Kualifikasi & Keterangan \\
\hline $90-100$ & Sangat Baik & Tidak perlu direvisi \\
\hline $75-89$ & Baik & Tidak perlu direvisi \\
\hline $65-74$ & Cukup & Direvisi \\
\hline $55-64$ & Kurang & Direvisi \\
\hline $0-54$ & Sangat Kurang & Direvisi \\
\hline
\end{tabular}




\section{Hasil Dan Pembahasan}

Menentukan mata pelajaran yang menjadi obyek pengembangan yaitu mata pelajaran dasar Design Grafis. Berikut Adalah Pokok Bahasan mata pelajaran dasar desain grafis berdasarkan silabus mata pelajaran dasar Design grafis.

Tabel 2. Sebaran Materi Desain Grafis

\begin{tabular}{cl}
\hline No & Kegiatan Pembelajaran/Materi pembelajaran Dasar Design Grafis \\
\hline 1 & Mengamati untuk mengidentifikasi, merumuskan masalah tentang design grafis \\
2 & Mengumpulkan data tentang design grafis (Pengenalan dan perkembangan design grafis) \\
3 & Mengolah data tentang desain gambar berbasis vektor. Mendeskripsikan produk design grafis vektor, \\
& dari jenis produk hingga mekanisme langkah-langkah pengimplementasian produk, dalam hal ini \\
& dipilih materi tentang banner. \\
4 & Mengomunikasikan aplikasi Corel Draw dalam desain gambar berbasis vektor. \\
\hline
\end{tabular}

Selanjutnya Menganalisis segala sesuatu yang dibutuhkan dalam pengembangan draft seperti analisis tujuan dan karakteristik mata pelajaran, analisis sumber belajar dan analisis karakteristik pebelajar; dalam hal ini peneliti melakukan observasi terkait pengembangan multimedia interaktif seperti mencari kegemaran siswa, sarana dan prasarana di Lab Multimedia SMK Negeri 1 Sawan, analisis kelayakan software dan hardware dan kemampuan SDM, dalam proses tersebut semua memenuhi syarat dikembangkan produk multimedia interaktif berbasis kontekstual budaya Bali. Melihat karakter mata pelajaran yang lebih banyak praktik dibandingkan dengan teori, maka pengembangan multimedia berbasis kontekstual budaya Bali dianggap sangat tepat digunakan untuk membantu siswa dalam proses belajar mengajar, siswa bisa belajar di rumah dengan melihat dan memahami video tutorial yang ditampilkan.

Proses pengembangan media, dalam tahap ini software yang digunakan untuk membuat multimedia interaktif berbasis kontekstual budaya Bali Pada Pembelajaran Design Grafis yaitu flash CS 5, untuk input suara menggunakan aplikasi Cool edit pro 2.1, dan perekam materi/pembuat video tutorial menggunakan aplikasi Camtasia studio 9, Adobe Photoshop sebagai software pengyunting gambar. Ke empat software tersebut disinergikan ke dalam produk multimedia interaktif, dalam aplikasi camtasia juga mampu melakukan proses converting sebuah video ke dalam format .swf, sehingga lebih gampang dalam pemanggilan perintah-perintah ke menu dalam multimedia interaktif. Back sound dalam multimedia interaktif dicari melalui youtube create dan audio library sehingga menghindari hak cipta dalam penggunaan musik, selain itu camtasia juga mampu menginput suara untuk dijalankan langsung ke video tutorial yang dibuat. Berikut contoh screenshot multimedia yang dikembangkan.
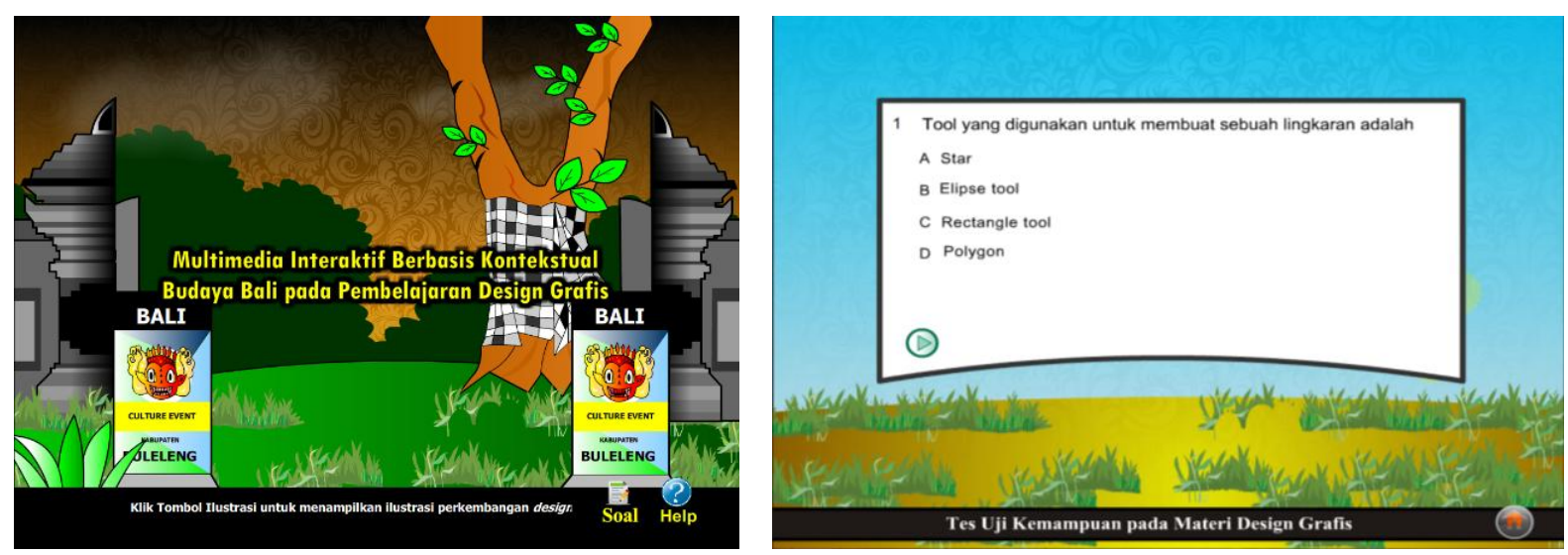

Gambar 1. Screenshot multimedia yang dikembangkan

Dalam halaman latihan soal tersebut diarahkan menuju kemampuan dalam menjalankan program adobe photoshop, jadi siswa dilatih untuk memahami langsung dari tool hingga fungsi masing-masing menu adobe photoshop dengan media soal. Jadi menurut pengertian Tutorial yaitu bantuan atau bimbingan belajar yang bersifat akademik oleh tutor kepada siswa untuk membantu kelancaran proses belajar madiri siswa secara 
perorangan atau kelompok berkaitan dengan materi ajar. Tutorial dilaksanakan secara tatap muka atau jarak jauh berdasarkan konsep belajar mandiri, dalam hal ini video yang ditampilkan akan memandu siswa untuk belajar di rumahnya/belajar mandiri.

Selanjutnya menuju tahap Produksi, dalam tahap ini peneliti langsung mendistribusikan hasil pengembangan produk ke dalam sebuah softcopy, selanjutnya menjalankan program dengan file master.exe. Tinjauan ahli dan uji coba terhadap produk, Uji coba meliputi tanggapan ahli isi yang langsung disesuaikan dengan silabus mata pelajaran dasar design grafis, ahli media, ahli desain, uji coba user/guru saat mengajar, uji coba untuk mencari respon siswa berupa uji perorangan, kelompok kecil dan mencari respon siswa dalam 1 kelas. Dalam proses tersebut Masing-masing ahli akan diberikan angket dengan kriteria sesuai dengan keahlian dari para ahli tersebut seperti tes/pengujian dan revisi.

Hasil penilaian oleh ahli media diperoleh persentase skor sebesar $85 \%$ berada pada kualifikasi baik, sehingga multimedia interaktif berbasis kontekstual budaya Bali Pada Pembelajaran Design Grafis tidak perlu di revisi. Hasil penilaian ahli media diperoleh persentase skor sebesar $89 \%$ berada pada kualifikasi baik, sehingga multimedia interaktif berbasis kontekstual budaya Bali Pada Pembelajaran Design Grafis tidak perlu direvisi. Hasil penilaian ahli isi maka dapat dilihat isi materi pembelajaran dalam multimedia interaktif sudah sesuai dengan silabus mata pelajaran dasar design grafis dan tidak perlu di revisi. Hasil penilaian oleh guru diperoleh bahwa materi dalam multimedia interaktif sudah sesuai dengan kriteria sebuah multimedia interaktif pada mata pelajaran dasar design grafis yang akan digunakan di semester II Program keahlian Multimedia.

Berdasarkan tanggapan siswa dalam uji perseorangan yang berjumlah 3 orang, keseluruhan menjawab "Ya" untuk pernyataan rasa senangnya belajar menggunakan multimedia interaktif berbasis kontekstual budaya Bali Pada Pembelajaran Design Grafis dan pernyataan bisa menjalankan multimedia interaktif tanpa bantuan guru. Berdasarkan hasil uji kelompok kecil maka dapat dihitung prosentase tingkat pencapaian multimedia interaktif berbasis kontekstual budaya Bali Pada Pembelajaran Design Grafis Hasil kalkulasi sebesar 90\% berada pada kualifikasi sangat baik, sehingga multimedia tidak perlu direvisi. Hasil uji lapangan (respons siswa) terhadap multimedia yang dikembangkan, diperoleh skor persentase sebesar $87 \%$ berada pada kualifikasi baik, sehingga multimedia tidak perlu direvisi.

\section{Simpulan}

Berdasarkan hasil analisis data dan pembahasan pada penelitian pengembangan multimedia interaktif berbasis kontekstual budaya Bali pada pemebelajaran design grafis, maka dapat disimpulkan bahwa rancang bangun multimedia interaktif berbasis kontekstual budaya Bali pada pembelajaran design grafis dibuat dengan menggunakan rancangan story board dan diagram aktivitas. Pengimplementasian menggunakan software Adobe Flash, Adobe Photoshop, Cool Edit Pro dan Camtasia. Produk Multimedia interaktif berbasis kontekstual budaya Bali pada pembelajaran design grafis menurut ahli isi dari hasil pengembangan pada aspek kelayakan isi materi yang ditampilkan, kelayakan penyajian dan kelayakan bahasa efektif sudah layak digunakan pada kelompok mata pelajaran produktif multimedia khususnya pada pembelajaran design grafis di kelas X Multimedia SMK Negeri 1 Sawan. Hasil pengembangan pada aspek konsep pembelajaran, proses pembelajaran, prosedur pengajaran, sudah efektif dan layak digunakan. Hal ini didasarkan pada penilaian uji user/guru pengajar. Hasil pengembangan pada aspek pembelajaran, kurikulum, isi materi, desain interface, balikan dan penanganan masalah sudah efektif dan layak digunakan di kelas X Multimedia SMK Negeri 1 Sawan pada pembelajaran design grafis. Pada aspek kejelasan, penampilan dan error, dapat diterima dan layak digunakan di kelas X Multimedia SMK Negeri 1 Sawan pada pembelajaran design grafis. Selanjutnya dari hasil pengembangan pada aspek keterpakaian, implementasi dan kebermanfaatan program, efektif layak digunakan di kelas X Multimedia SMK Negeri 1 Sawan pada pembelajaran design grafis.

\section{Daftar Pustaka}

Arikunto, S. 2008. Dasar-dasar evaluasi. Jakarta: Bumi aksara.

Ghufron, Anik dkk. 2007. Panduan Penelitian dan Pengembangan Bidang Pendidikan dan Pembelajaran. Yogyakarta: Lembaga Penelitian UNY.

Lee, Szu Hsin;Tseng, Hui Ching, 2008. "Investigation of Technology Integrated Instruction in Art Education: A Case Study of Exploring Learning Achievement" Journal of Educational Multimedia and Hypermedia, 17 (3), pg. 337-361. 
Mochamad Miswar Hadibin, Bambang Eka Purnama, Gesang Kritianto, 2012."Pembangunan Media Pembelajaran Teknik Komputer Jaringan Kelas X Semster Ganjil Pada Sekolah Menengah Kejuruan Taruna Bangsa Pati Berbasis Multimedia Interaktif”, Jurnal Speed 13, Vol 9 No 2:432-437.

Sudarma, I K. \& I M. Tegeh. 2007. Penelitian Pengembangan (Pengembangan Produk-Produk di Bidang Teknologi Pendidikan). Makalah Disajikan dalam Pelatihan Penyusunan Proposal Penelitian Pengembangan di Jurusan Teknologi Pendidikan Undiksha. Singaraja:Januari.

Sugiyono. 2013. Metode Penelitian Pendidikan (Pendekatan Kuantitatif, Kualitatif, dan R\&D), Bandung : Alfabeta.

Trianto. 2007. Model-model Pembelajaran Inovatif Berorientasi Konstruktivistik. Jakarta : Prestasi Pustaka

Uno,Hamzah.(2009). Model Pembelajaran Menciptakan Proses Belajar Mengajar yang Kreatif dan Efektif.Jakarta: PT Bumi Aksara

Wang, Ling, 2008. "Developing and Evaluating an Interactive Multimedia Instructional Tool: Learning Outcomes and User Experiences of Optometry Students", Journal of Educational Multimedia and Hypermedia, 17(1) pg. 43-57. 